\title{
The Use of Instagram in an Effort to Attract Fans of the PSIM Jogja Soccer Club
}

\author{
Sandrianna Ozora ${ }^{1}$ Eko Harry Susanto ${ }^{1 *}$
}

\author{
${ }^{1}$ Faculty of Communication, Universitas Tarumanagara, Jakarta 11440, Indonesia \\ *Corresponding author. Email: ekos@fikom.untar.ac.id
}

\begin{abstract}
The era of globalization has placed the role of communication technology in a very strategic position in eliminating distance, space, time, and other barriers to communication. Communication technology is a new communication using technology that makes it easier for humans to receive and convey messages through a medium. Social media is a web-based feature that can network and support people to communicate and connect with one another. Social media users can also carry out various forms of exchange, collaboration and get to know each other in written, visual and audiovisual forms. Such as Facebook, Twitter, Blog, Instagram, and others that are commonly used today. When the media dominates the internet, Ditya Fajar as PSIM Jogja's content strategist said that's where the football club community takes advantage of the opportunities that are in sight, and the PSIM Jogja soccer club is one of the many football club communities that use Instagram social media as a bridge in an effort to attract their fans, instagram also used as the medium of a official marketing merchandise. Therefore, discussing the use of Instagram social media in an effort to attract fans of the PSIM Jogja football club. This research method is qualitative with a study method based on the results of data from key informants / sources who have influence in this study. Based on the results of the interview, social media Instagram has made an effort to attract fans of the PSIM Jogja football club. This research explains how the use of instagram as social media in an effort to attract fans, instagram also used as the medium of an official marketing merchandise.
\end{abstract}

\section{Keywords: Social media instagram, PSIM Jogja, Supporter, Sport Communication}

\section{INTRODUCTION}

Social media is used to distribute and produce media content in the form of informations to be conveyed. Nowadays everyone uses social media instagram to communicate, because social media is a place where people can participate and create a work in the form of writing and visuals. An Opinion Carr \& Hayes [1] states that Social Media is an internet-based media that can allow users the opportunity to interact and present themselves, either instantly or delayedly, with a wide audience or not. According to Bambang in Atmoko [2] Instagram is a smartphone application that has the same function as other social media. But instagram can also inspire, as well as increase creativity. Indonesians have the number of active users using social media instagram reached 61,610,000. According to napoleoncat's recent report, which is a social media marketing company based in Warsawa, Poland [3]. According to Rohmadi [4] Instagram can be used as a medium for sharing, for portfolios, promotional media, and endorsment. At this time, a company and many people used social media instagram as a tool to introduce

themselves to the public as well as a medium of marketing. One of them is used by football clubs in Yogyakarta. Football is one of the most popular sports in
Indonesia, ranging from children to adults who are usually loved by men. PSIM or Perserikatan Sepak Bola Indonesia Mataram is a football club established on September 5, 1929 in Yogyakarta. Instagram social media management can provide a specific image for a company or a person. Therefore, PSIM Jogja has a marketing strategy. Marketing strategy according to Kotler and Amstrong [5] is a marketing logic where the company hopes to create value for customers and be able to achieve profitable relationships with customers. This strategy is carried out so that PSIM can provide good content / advertising. Advertising is one of the special forms of communication that is usually used by entrepreneurs to direct persuasion communication to target buyers and the public. according to Kasali [6] defines advertising as "A medium that is static and prioritizes visual messages". This strategy is carried out so that PSIM fans can continue to support PSIM. This research explains how the use of instagram as social media in an effort to attract fans, instagram also used as the medium of a official marketing merchandise.

\subsection{Related Work}

Below are some previous researches which become the references for this research: 


\subsubsection{Social Media's Influence On Social Changes In Society}

This researcher aims to know and understand of social media and identify and know the influence of social media on social change in Indonesia. With the advent of social media has affected social life in society, changes in social relationships or as a change to balance.

\subsubsection{Instagram's Role As A Social Media In Increasing Sales At The Yumik Kediri Cafe}

The role of social media in increasing sales in Cafe Yumilk can be seen from the spread of questionnaires to consumers of Cafe Yumilk, The author concluded that the use of social media instagram is very effective.Because with the social media Instagram enlightens Cafe Yumilk in doing promotions that can be done directly and simply and can directly face customers if anyone wants to be asked or wants to criticize the cafe Yumilk.

\subsubsection{The Effects Of Advertising On Consumers Attitude And Its Impact On Buyers Decision}

Advertising has a positive and significant influence on consumer attitudes.This indicates that advertising can influence consumers' likes or dislikes of products. The better the advertisement, the more consumers will like the product.

\subsubsection{Instagram's Role As A Social Media In Building The Brand Image Of Aryaduta Lippo Village}

Instagram social media plays an important role in building the brand image done.Building a brand image through Instagram social media is considered very effective and able to build awareness to the community. Facilities and all promos offered by Aryaduta Lippo Village managed to reach and understand the public, as evidenced by the followers or followers of Aryaduta Lippo Village who are quite numerous.

\subsection{Our Contribution}

This paper presents the results of research on the PSIM Jogja football club that uses social Instagram social media as a bridge in an effort to attract their fans, instagram also used as the medium of a official marketing merchandise.

\subsection{Paper Structure}

The paper is structured in 5 sections as follows: section 1 is an introduction to the problems in research as well as the preliminary research used by the author in research. Section 2 author describes the theory used in the research. Section 3 is an explanation of the methods the research uses in determining, collecting, and processing research data. Section 4 is the findings and discussion based on processed data and is linked to the theory used in the research. In section 5 the author draws an overall conclusion regarding the research carried out then followed by an acknowledgment of the author's origin of institution. Last, was references included in this paper.

\section{BACKGROUND}

\subsection{Communication Technology}

The era of globalization has put the role of communication technology into a very strategic position in eliminating distance, space, time, and other obstacles in communication. Rogers in Susanto [7] communication technology is described as an entity that can be explained in three ways, namely: 1 . All new communication systems that have a level of interactivity and can be utilized directly in face-to-face between two people assisted by computers. 2 . New media may also experience errors if the message is delivered to a large audience. 3. Communication technology is out of sync, which means it has the ability to send or receive messages in a timely manner for the individual, wherever the individual in Susanto. From the description above, researchers concluded that communication technology is the development of new communication using technology that makes it easier for humans to interact by receiving and conveying messages through a medium.

\subsection{Instagram Social Media}

Instagram is a social media application from smartphones that is one of the digital media that has almost the same function as Twitter, but the difference lies in taking photos in the form or place to share information with its users. Instagram can also inspire its users and can also increase creativity, because Instagram has features that can make photos more beautiful, more artistic and become better.

\subsection{Marketing Strategies}

Marketing strategy according to Kotler and Amstrong [5] is a marketing logic where the company hopes to create value for customers and be able to achieve profitable relationships with customers. A marketing strategy is a plan that outlines the company's expectations of the impact of various activities or marketing programs on product demand on specific target markets. Companies can use two or more marketing programs simultaneously, because each type of program such as sales promotion, personal selling, customer service, or product development has different influences on demand. Marketing Strategy Marketing strategy is marketing that seeks to instill the company and its products in the minds of customers. This strategy aims to achieve how to win the market. Here are four components in the marketing strategy, as follows in Widia Resti Ayu [8] : 1. 
Segmentation: A market is made up of many buyers, and buyers differ in one way or another. For example, they differ in their desirability, resources, location, purchasing attitudes and purchasing practices. It cannot be denied that each individual is unique, each individual still has various or unique desires, needs, motivations. 2. Target: after dividing and mapping the market into several segments, then what is done is determining the target market to be targeted. Targeting is a strategy to allocate company resources effectively, because the resources they have are limited. By determining the target to be targeted, efforts will be more focused. 3. Positioning: a strategy to seize position in the minds of consumers, so this strategy concerns how to build trust, confidence, and competition for customers. Consumers play a key role in the purchase and use of company products. The availability of various options, each of which has its positive and negative sides, makes consumers always compare the products offered by the company with one another. For this reason, positioning is needed so that the image of the product or company can be formed in accordance with the intentions and goals of the company. So, positioning plays a role in marketing the company's products because building positioning means building trust from consumers. Building trust means demonstrating a commitment that the company offers more than other companies.

\subsection{Sports Communication}

According to Susanto [9] The development of the world of sports which is always related to communication is an interesting study to be initiated in the discourse of communication science in Indonesia. Indeed, if you look closely, the practice of communication in sports (sport communication) has developed. The World Cup soccer party makes a democratic party get a competition, at least in the attention of the audience and the media. The flags of political parties and presidential candidates that adorn the democratic party side by side with the flags of the countries participating in the World Cup voluntarily installed by football fans. Even in various places where young people gather, the flags and symbols associated with the World Cup are far more dominant than the bustle of national political contestation.

Watching the World Cup together is held in various places, ranging from official and paid in star hotels to watching events together for free and without an official license held in coffee shops. The conversation in the world of social media is also filled with issues surrounding the World Cup. In line with the hubbub of watching together and the crowd of social media, this was accompanied by mass media coverage which allocated a larger portion of time and space for World Cup coverage. Newspapers provide special supplements related to the World Cup and television stations compete for World Cup broadcasting rights.

Therefore, a sports activity cannot be separated from the communication carried out in the game or outside the game carried out by the audience or fans of an existing football club.

\subsection{Advertising}

Advertising is a special form of communication that is usually used by entrepreneurs to direct persuasion communication to target buyers and society. according to Kasali [6] defines advertising as "a static media and prioritizes visual messages". Choosing advertising media is determined based on the frequency, reach of consumers, and the impact that these advertisements have on consumers. Each advertising medium has its own advantages and disadvantages in advertising a product. As a marketer, you must be able to choose the right advertising media so that advertisements can reach consumers effectively and efficiently.

\section{METHODS}

Researchers used a qualitative approach. Denzin and Lincoln in Herdiansyah define that quantitative research is more aimed at achieving in-depth understanding of specific organizations or events rather than describing the surface part of a large sample of a population. The method that researchers will use in this research is a case study. According to Creswell in Herdiansyah [10]. A case study is a model that emphasizes the exploration of a system that is limited to a case or a few cases in detail, accompanied by exploring in-depth data. The subjects of this research are sources or informants who know the problem that the researcher will examine, and are willing to provide the researcher with information. Moloeng defines [11] "an informant is a person who can provide information or information about the problem being researched and can act as a resource during the research process. Among the many informants, there are those called key informants or main informants, namely someone or several people who know the most about the object of research under study [12].

The subjects that researchers will interview for this research are:

1. Social media manager for Instagram PSIM Jogja

2. Fans of the Jogja PSIM football club

Sugiyono explains in his book that the object of research is an attribute or nature of a person. Objects that have certain variations are determined by the researcher to study and then draw conclusions [13]. In this study, the research is the use of Instagram social media that the PSIM Jogja football club provides in an effort to attract its fans who are the objects.

To strengthen this research, the data collection methods used by researchers used interviews, non-participant observation, literature study and online data search. 
a) In this study the authors conducted interviews with fans of the PSIM Jogja football club, and the manager of the PSIM Jogja football club instagram. These parties are the main keys in achieving the objectives of this research.

b) In this case the author makes observations through observations that the author sees and also hears directly at the research place and based on the opinions, judgments, feelings, hopes, and responses of sources related to their experiences with the object of research, namely the use of Instagram social media in an effort to attract fans PSIM Jogja football club.

c) In this study, the authors make use of books and theories that have been studied and read related to the field of Communication Studies, research problems and research methods as data sources and theoretical foundations that support this research. The literature study is obtained from various sources of scientific journals that support this research. All journals and readings that have been used are reviewed and read and taken as support for the writing of this scientific paper.

d) In this study the authors use online sources as supporting data or additional for research information needs.

\section{FINDINGS AND DISCUSSIONS}

According to Bambang's opinion in Atmoko [2] Instagram social media is a digital media that can increase creativity and provide inspiration for its users, because Instagram has features that can make photos more artistic and good.

According to Gunelius [14] the purpose of using social media is to actively build relationships with consumers. As:

"Because I think Instagram is the most appropriate social media for us to communicate with fans. Because from our posts, we can see what our club followers are like, we can post interesting content that our followers keep in mind and if our Instagram is interesting, fans will definitely continue to support and support us, not moving around. " (Ditya Fajar, 18 November 2020).

First, building a brand is very important for PSIM to attract fans. Therefore, PSIM uses Instagram.

"Wow, in my opinion, Instagram is very important, nowadays we play Instagram really, on average all information is seen from Instagram, starting from gossip, news updates, to just going somewhere, the litany is from Instagram, so we use Instagram." (Ditya Fajar, 18 November 2020).

Second, PSIM uses publicity to disseminate or share information to fans of the PSIM Jogja football club.

"It's really effective, until we create a promotional event too, like PSIM store, we all promote Instagram endorsement, because reaching people is much easier." (Ditya Fajar, 18 November 2020).
Third, promotion through Instagram is carried out by PSIM to promote PSIM merchandise issued by PSIM Store. Fourth, market research is used by PSIM Jogja by analyzing PSIM Jogja's Instagram insights, so that PSIM can find out their active hours, age, location, and gender of followers.

According to Susanto [9] The development of the world of sports which is always related to communication is an interesting study in the discourse of communication science in Indonesia. Therefore, sports communication is very important, carried out outside the field or on the field

"In playing ball, communication is not only on the field, right on the field, it is certain, but the impact of supporters or fans on the field is extraordinary. Like I said earlier, if the fans or supporters are not enthusiastic, the players will definitely feel it too. " (Ditya Fajar, 18 November 2020).

This statement was supported by one of the author's sources who stated that:

"People see that losing must be sad, but keep in mind that if you have to keep your spirits up through the content, I'm a fan and I think like, oh yeah, I'll be a mainstay - I'm not excited. Meanwhile, if you support even from outside the field, surely the players will also be happy to see the supporters. The energy is different. " (Vinnie Octa, 19 November 2020).

According to Kasali [6] advertising is "a media that is static and secures visual messages". As a marketer, the selection of media and advertisements to be distributed must be appropriate, so that messages can be conveyed to consumers effectively and efficiently.

"For content, it has to be interesting, right, the content is about things that are more viral, then most importantly the visuals have to be really interesting, because people will see first from the outside, namely the visuals. The caption must also be interesting, so that many people like and share it with people. Because if on Instagram there are many who like and share, it can be entered into explore other Instagram users and many people see. " (Ditya Fajar, 18 November 2020).

Research sources said that the uploaded content must attract the attention of the audience. Because the audience will see the visual first.

"We often hold giveaway, because usually people are the most excited and they seem more interested in giving away. If people like the content, automatically a lot of content will be seen and shared. So that's one way anyway. " (Ditya Fajar, 18 November 2020).

PSIM Jogja holds a giveaway as a way to promote and advertise the PSIM Jogja Instagram account. "The problem is, most often. If you lose, San is usually bullied by existing social media, from fans of other football clubs, to the point that a lot of people are bully too. Now the player or fan is 
really down, from there in the next match he is pessimistic. For the solution, we make the losing content not sad, we play it in the headlines and captions. Then if it's corona like now, I'm really confused about what content to make, because there is no league to compete in San, so it's a new challenge, how to keep fans from running away. I usually like to find inspiration and reference content, because it must be interesting. Then the other challenge is how do we continue to maintain fans and attract new fans. We use the strategy we have, mainly how to see our followers so that we can give them what they like. "(Ditya Fajar, 18 November 2020).

\section{CONCLUSIONS}

Based on the results of the research carried out, PSIM Jogja actively uses social media Instagram to attract fans, by providing and sharing information about the activities of the PSIM Jogja football club, making interesting content designs, holding merchandise giveaway.

PSIM Jogja has several obstacles, such as when PSIM lost a match, lots of negative comments (bullying), difficulties in creating content during the pandemic, COVID-19, and ways to continue to maintain PSIM Jogja fans via Instagram. PSIM has a strategy that becomes a solution in facing obstacles, by making headlines that keep encouraging on PSIM content, seeing inspiration and references that are being discussed, and implementing marketing strategies by paying attention to market segmentation, seeing targets, and positioning.

PSIM Jogja introduces and promotes official PSIM Jogja football club merchandise through Instagram, by holding a giveaway to introduce and provide attractive offers to promote.

\section{ACKNOWLEDGMENT}

Based on the results of the research carried out, PSIM Jogja actively uses social media Instagram to attract fans, by providing and sharing information about the activities of the PSIM Jogja football club, making interesting content designs, holding merchandise giveaway.

PSIM Jogja has several obstacles, such as when PSIM lost a match, lots of negative comments (bullying), difficulties in creating content during the pandemic, COVID-19, and ways to continue to maintain PSIM Jogja fans via Instagram. PSIM has a strategy that becomes a solution in facing obstacles, by making headlines that keep encouraging on PSIM content, seeing inspiration and references that are being discussed, and implementing marketing strategies by paying attention to market segmentation, seeing targets, and positioning.
PSIM Jogja introduces and promotes official PSIM Jogja football club merchandise through Instagram, by holding a giveaway to introduce and provide attractive offers to promote.

\section{REFERENCES}

[1] Caleb T. Carr \& Rebecca A. Hayes (2015). Jurnal penggunaan media sosial, 164. September 21, 2020. Terarsip di: https://core.ac.uk/download/pdf/234134029 .pdf

[2] Atmoko (2012). Gaya Bahasa Dalam Sosial Media Instagram. Jurnal media sosial, 11. September 18, 2020. Terarsip di: https://ikipwidyadarmasurabaya.ac. id/wp-content/uploads/2019/07/261-278-rini-UWK.pdf

[3] NapoleonCat (2019). Sebanyak inikah pengguna Instagram di Indonesia? September 10, 2020. KompasTekno database https://tekno.kompas.com/read/ 2019/12/23/14020057/sebanyak-inikah-jumlahpengguna-instagram-di-indonesia\#: :text=Secara $\% 20$ global\%2C\%20jumlah\%20pengguna\%20aktif,aktif\%20 mengunggah $\% 20$ Stories $\% 20$ tiap $\% 20$ harinya.

[4] Rohmadi, A. (2016). Tips Produktif Ber-social Media. Jakarta: Elex Media Komputindo.

[5] Kotler \& Amstrong (2012). Jurnal strategi pemasaran, 6 - 7. September 21, 2020. Terarsip di: http://library.binus.ac.id/eColls/eThesisdoc/Bab2/20122-00942-SI\%20Bab2001.pdf

[6]Kasali (2011). Jurnal periklanan, 9. September 21, 2020. Terarsip di: http://repository.uma.ac.id/bitstream/ 123456789/1886/5/128320020_file5.pdf

[7] Susanto (2018). Upaya Gopay Dalam Mempertahankan Minat Pembelian Mhasisa Di Kantin Universitas Tarumanagara Kampus 1. 8. September 18, 2020. Terarsip di: https://journal.untar.ac.id/index.php/ prologia/article/view/6674

[8] Widia Resti Ayu (2020). Strategi Pemasaran Dalam Meningkatkan Penjualan Pada Toko Bag Corner Ponogoro. September 23, 2020. Fakultas Ekonomi Dan Bisnis Islam Institut Agama Islam Negeri Ponogoro. Terarsip di: http://etheses.iainponorogo.ac.id/8891/1/ SKRIPSI\%20UPLOAD.pdf

[9] Susanto, Eko Harry. (2014). Sport, Komunikasi, dan Audiens, vi - vii. Oktober 10, 2020. Aspikom. 
[10] Herdiansyah, Haris. (2010). Metedologi Penelitian Kualitatis Untuk Ilmu-Ilmu Sosial. Jakarta Selatan: Salemba Humanika.

[11] Moleong, Lexy J. (2009). Metode Penelitian Kualitatif. (Edisi Revisi). Bandung: Remaja Rosdakarya.

[12] Ardianto, Elvinaro. 2011. Metode Penelitian untuk Public Relations Kuantitatif dan Kualitatif (Ed Revisi).

Bandung: Simbiosa Rekatama Media.

[13] Sugiyono. (2010). Metode Penelitian Kuantitatif Kualitatif dan R\&D. Bandung: Alfabeta CV.

[14] Gunelius (2011). Peran Media Sosial Dalam Membangun Brand Image. Jurnal media sosial, 23. September 18, 2020. Terarsip di: https://bbs.binus.ac.id/ gbm/2017/03/08/social-media-marketing/ 